DOI: $10.7596 /$ taksad.v4i1.400

\title{
İstahrî ve Mesâlikü’l-Memâlik’i
}

\section{Murat Ăgarı ${ }^{1}$}

\section{$\ddot{O} \mathbf{z}$}

Tarihî Coğrafya olarak adlandırdığımız alanda verilen eserler, içeriklerinin çeşitliliği ve verdiği bilgilerin geniş bir alana hitâb etmesi sebebiyle Ortaçağ tarihi ve tarihçiliği açısından önemli kaynaklardır. Bu alanda telif edilen eserlerde coğrafî bilgiler ağırlıkı olmasına rağmen tarihî bilgiler de bulunmaktadır. Ayrıca kültürel, ekonomik, etnolojik, antropolojik, demografik ve folklorik bilgi türlerine de rastlanmaktadır. Söz konusu bilgiler tarihçilerin itibar göstermesi gereken bilgilerdir. Zira, tarihî bilgi, sadece siyasî olayların ardı ardına gelmesi ile oluşan bir bilgi yığınağı değildir. Siyasî olayların coğrafî, ekonomik, kültürel, folklorik vs. bilgiler tarafından desteklenmesi gerekir. $\mathrm{Bu}$ şekilde yapılacak bir değerlendirme tarihi daha anlaşılır kılacaktır.

Bu eserlerden birisi İstahrî'nin Mesâlikü'l-Memâlik'idir. Eserde coğrafî bilgiler ağırlıktadır. Bunun yanında bahsettiğimiz bilgilerden de çok miktarda bulunmaktadır. İstahrî, İslâm dünyasını 20 bölgeye ayırarak anlatmıştır. Özellikle Maverâünnehir bölgesi ve Türkler hakkında detaylı bilgiler vermektedir. $\mathrm{Bu}$ çalışmada, çok geniş bir bilgi ağına sahip olan Mesâlik'teki bilgiler değerlendirilmiştir.

Anahtar Kelimeler: Coğrafya, İstahrî, Mesâlikü'l-Memâlik, Ortaçă̆ tarihi, İslâm Coğrafyacılı̆̆g.

\footnotetext{
${ }^{1}$ Doç. Dr. Murat Ağarı, Karabük Üniversitesi, Edebiyat Fakültesi, Tarih Bölümü.
} 


\section{Al-Istakhri and his Masalik al-Mamalik}

\section{Summary}

The works written at historical geography area have very rich information and these works are also important sources for Middle Ages history works. Historical geography works includes especially geographic and historical information. Besides they have cultural, ethnologic, anthropologic, demographic and folkloric information too. These information are important for historians and they have to deal with them. Because, history is not information masses, arranged in order by political facts. Political facts must be supported by geographic, cultural information, and so forth. Such evaluation of political facts would make history to be understood.

One of these works is Masalik al-Mamalik of Istakhri. As mentioned above, it is laden with political information. Besides, there have been other accounts, especially about Turks and Mavara al Nahr. This paper deals with the information at Masalik.

Keywords: Geography, Istakhri, Masalik al-Mamalik, Middle Ages history, Islamic Geography.

\section{Hayatı ve Eserleri}

Tam adı Ebu İshak İbrahim b. Muhammed İstahrî’dir. Kerhî olarak da bilinir. Kaynaklarda hayatı hakkında detaylı bilgi yoktur. Coğrafya kitabında da hal tercümesine rastlanmaz. İran'ın İstahr şehrindendir. Asya'nın çoğu bölgelerini Hint sınırına kadar İslâm ülkelerini ziyaret etmiştir.İbn Havkal'in eserinden 340/ 952 yılı civarında İstahrî'nin İbn Havkal ile görüşmüş ve onunla çağdaş olduğunu öğreniyoruz.Eseri hakkında daha önce Belhî'nin yazdığı eserin yeniden işlenerek meydana getirildiği şeklinde bir iddia bulunmaktadır. İbn Havkal ise kendisiyle görüştügünde ona eserini teslim ederek, kendi kitabı üzerinde bir takım değişikliklerde bulunmasını istemiştir. Bu durumda onun X. asrın ilk yarısında hayatta olduğu ve muhtemelen de 340/ 952'den sonra vefat ettiğini söyleyebiliriz. ${ }^{2}$

İstahrî'nin bilinen ve günümüze ulaşan tek eseriMesâlikü'l-Memâlik'tir. ${ }^{3}$ Eser ilk olarak J. H. Moeller tarafından 1839'da özet şeklinde yayınlanmış, daha sonra İngilizce tercümesiyle beraber 1849 'da fasiküller halinde Hamburg'da tekrar basılmıştır. F. Meyer tarafından 1856' da bir baskısı daha yapılmıştır. M. J. de Goeje tarafından yapılan incelemesi ACES'nin içinde 1870'de yayınlanmıştır. Eserde renkli haritalar mevcuttur. İkinci bir tercümesi R. B. Burke tarafından yapılarak Philedalphia'da 1928'de yayınlanmıştır. Daha

\footnotetext{
2 İstahrî ve diğer İslâm coğrafyacılarının hayatları ve eserleri için bkz.: Murat Ağarı, İslâm Coğrafyacılığı ve Müslüman Coğrafyacılar(Doğuşu-Geliş̧imi ve Temsilcileri), Kitabevi yay., İstanbul 2002.

3 İstahrî, Ebî İshak İbrahim b. Muhammed el-Fârisî, Mesâlikü'l-Memâlik, Brill 1927.
} 
sonra Muhammed Cabir Abdulâl Hînî tarafından gözden geçirilen bir baskısı 1961 yılında Kahire'de yayınlanmış; bir başka baskısı da Bağdat'ta 1966'da gerçekleştirilmiştir. Atlas şeklinde düzenlenen bu eserde bilginin yanında bolca harita bulunmaktadır. ${ }^{4}$

\section{Mesâlikü'l-Memâlik}

İstahrî, eserini 20 başlığa ayırmıştır. Giriş bölümünde kitabını yazma amacını ve tasnifini şu ifadelerle dile getirir: "Kitabımda yeryüzünün iklim bölgelerini anlattım. Bununla İslâm ülkelerini, tafsilâtıyla şehirlerini kastediyorum.Yoksa, kastım yeryüzünün içinde bulunduğu yedi iklim ${ }^{6}$ değildir. Üstelik her bir kıtayı teker teker anlattım ve tasvir ettim. Üzerindeki yerleşim yerlerini, şehirleri, gölleri, denizleri de anlattım. Camilerden ve etrafında bulunanlardan bahsettim. Okuyanı sıkmaması için lafı uzatmadım. Kitabımda bunları anlatmamın sebebi, bildiğim kadarıyla kimsenin bahsetmediği iklimlerden bahsetmektir. $\mathrm{O}$ şehirlerin, dağların, nehirlerin ve mesâfelerin bilgileri tarih kitaplarında bulunur. Benim kastettiğim bunlar değildir. Kastım etrafını okyanusların/ muhît çevirdiği tüm dünyadır. Birisi oraya baktığında zihninde bir harita oluşturamaz. Biz çalışmamızda iklimlerin birbirlerine birleştikleri yerleri, her bir iklimin bulunduğu yeri anlattık ki, birisi ayrıntılı bir şekilde o iklimden haberdar olsun. İslâm ülkelerini 20 iklime böldüm ve Arap yurdundan başladım. Orayı tek iklim kabul ettim. Zira şehirlerin anası Mekke ve Kâbe oradadır. Burası iklimlerin ortasıdır. Arap yurdunun ardından Arap yurdunun çoğunu kuşattığı için Fars denizini ${ }^{7}$ anlattım. Ardından Mısır'ı içine alacak şekilde Magrib'i, Şam’ı, Rum denizini, ${ }^{8}$ el-Cezîre'yi, Irak'1, Huzistân'1, Fars'1, Kirmân'1, Mansûra'yı ve ona bağlı Sind, Hind ve İslâm ülkelerini, Azerbaycân'1 ve ona bağlı yerleri, Cibâl'i, Deylem'i, Hazar denizini, Fars ve Horasân arasında kalan bozkırı, Sicistân'ı ve ona bağlı yerleri, Horasân'1 ve Mâverâünnehir'i anlattım."9

Eserinin başında ana hatlarıyla bir Dünya tasavvuru oluşturan İstahrî, buçerçeveyi şu şekilde verir: "İslâm ülkelerinin doğusunda Hint toprakları ve Fars denizi vardır. Batısında Rum ülkesi ve bu ülkeye bitişik olan İrmen, Lân, Rân, Serir, Hazar, Rus, Bulgâr, Sakâlibe ${ }^{10}$ ve Türklerden bir tâife bulunur. Kuzeyinde Çin ülkesi ile bu ülkeye bitişik Türk ülkeleri yer

\footnotetext{
${ }^{4}$ Bkz.: Ağarı, İslam Cŏgrafyacılı̆̆l, ss. 337-338.

${ }^{5}$ İklim, ekvatordan kuzey kutbuna doğru yeryüzünün ayrıldığı yedi bölgeden her biri, coğrafî alan, mıntıka, diyardır. Bkz.: Mahmut Ak, "İklim”, DIA, C.: 22, s. 28 vd.

${ }^{6}$ Yedi İklim konusu ile ilgili olarak bkz.: Murat Ağarı, "İslam Coğrafyacılarında Yedi İklim Anlayışı”, Ankara Üniversitesi Illahiyat Fakültesi Dergisi, C.: 47, Say1: II, 2006, ss.: 157-176.

${ }^{7}$ Farsdenizi ile kastedilen Hintokyanusudur.

${ }^{8}$ Rumdenizi ile kastedilen Akdenizdir.

${ }^{9}$ İstahrî, Mesâlik, ss. 2-4.

${ }^{10}$ Sakâlibe ile kastedilen Slav uluslarıdır.
} 
alır. Güneyinde Fars denizi mevcuttur. Rum ülkesinin doğusunda İslâm ülkeleri vardır. Batısında ve güneyinde Okyanus/ Muhît bulunur. Kuzeyi Çin topraklarına sınırdır. Türk ülkeleri ile Rum ülkesi arasında kalan Sakâlibe ile diğer milletleri Rum ülkesi içerisinde değerlendirdim. Çin ülkesinin doğusunda ve kuzeyinde Okyanus bulunur. Güneyinde İslâm ülkeleri ve Hind toprakları, batısında Okyanus vardır. Yecüc ve Mecüc ${ }^{11}$ ülkesi ile onun arka taraflarını bu ülke ile Okyanus arasında değerlendirdim. Hind ülkesinin doğusunda Fars denizi, batısında ve güneyinde İslâm ülkeleri, kuzeyinde Çin ülkesi vardır. İşte buralar zikrettiğim ülkelerin sınırlarıdır.",12

Daha sonra Fars, Rum ve Hazar denizlerinden bahseden ${ }^{13}$ İstahrî, ana hatlarıyla Türk ülkeleri hakkında şu bilgiyi verir: "Türk ülkeleri farklıdır. ${ }^{14}$ Uygur/ Toğuzğuz ülkelerinin sınırı Hazarlar, Kîmaklar/ Kîmâkiyye, Karluklar/ Hazleciyye ve Bulgâr toprakları ile İslâm ülkelerinin sınırı arasındadır. Yani, Cürcân, Fârâb ve Esbîcâb arasındadır. Kîmak/ Kîmakiyye ülkesi kuzeyden Karlukların/ Hazleciyye arka tarafından başlayarak Oğuzlar/ Guzziyye, Kırgızlar/ Hırhîz ve Sakâlibe arasındadır. Yecüc kuzeyde, Kîmaklar/ Kîmakiyye ve Sakâlibe'nin arka tarafındadır. Onların ülkelerini ve yerlerini ancak Allah bilir. Kırgızların/ Hırhîz toprakları Uygurlar/ Toğuzğuz, Kîmaklar/ Kîmâkiyye toprakları, Okyanus ve Karluklar/ Hazleciyye arasındadır.Uygurlar/ Toğuzğuz, Tibet, Karluklar/ Hazleciyye toprakları, Kırgızlar/ Hırhîz ve Çin ülkesi arasındadır."15“Hazarlar, bu soydan/ Türkler bir kavme verilen isimdir. Bunların ülkeleri İtil denilen gelişmiş bir şehirdir. Bu isim, şehrin kenarından geçerek Hazar'a dökülen nehrin ismidir. İtil, yerleşim yeri çok ve geniş bir şehir değildir. Hazar denizi, Serîr, Rus ve Oğuzlar/ Guzziyye arasında bir mevkidir. Tibet, Çin toprakları, Hind, Karluklar/ Hazleciyye, Uygurlar/ Toğuzğuz ve Fars denizi arasında kalan bir bölgedir. Topraklarının bir kısmı Hind, bir kısmı da Çin toprakları içerisindedir. Burada oturan bir hükümdârları vardır."16

Bu ana Giriş’ten sonra İstahrî, bölgeleri anlatmaya başlar.

\footnotetext{
${ }^{11} Y e$ 'cûcveMe'cûc, Zülkarneyn döneminde ortaya çıkan ve kıyametin kopmasına yakın dönemde zuhur ederek yeryüzünde bozgunculuk yapacak olan ve Hz. Nûh'un oğlu Yâfes'in soyundan gelen bir topluluktur. Tâvil, Tâyis ve Mensik diye üç kola ayrılmıştır. Birinciler uzun, ikinciler orta, üçüncüler ise kulaklarından birini döşek, diğerini yorgan yapacak kadar kısa boyludur; hiçbiri kendi soyundan bin çocuk dünyaya getirmeden ölmez. Hz. Îsâ'nın nüzûlünden önce seddin arkasından çıkıp yeryüzünde bozgunculuk yapacaklardır. Bkz.: İlyas Çelebi, "Ye'cûc Me'cûc", DİA, C.: 43, ss. 373-375.

12 İstahrî, Mesâlik, ss. 5-6.

13 İstahrî, Mesâlik, ss. 6-9.

14 İslâm coğrafyacılarının eserlerindeki Türklerin anlatımı ile ilgili olarak bkz.:Murat Ağarı, "Coğrafya Eserlerindeki Türklerle İlgili Bilgilerin Irak ve Belh Coğrafya Ekollerine Göre Değerlendirilmesi”, YYÜ Sosyal Bilimler Enstitüsü Dergisi, Y11: 2005, Say1: 8, ss: 35-66.

${ }^{15}$ İstahrî, Mesâlik, ss. 9-10.

${ }^{16}$ İstahrî, Mesâlik, s. 10.
} 


\section{Arap Yurdu}

İstahrî, Arap yurdundan başlama sebebini şu ifadelerle dile getirir: "Kıblenin ve şehirlerin anası Mekke'nin orada bulunması, Arapların ülkesi ve vatanı olması nedeniyle Arap yurdundan başladım."17 Daha sonra, bundan sonraki bölümlerde de uyguladığı üzere bölgenin çevresini anlatır: "Etrafını Fars denizi çevirir. Bu deniz Dicle’nin sularının döküldüğü Abbâdân'dan başlar, Bahreyn'e doğru ilerler ve Ummân'da son bulur. Buradan Mehre, Hadramût ve Aden'e doğru kıvrılır; Yemen sahillerinde ve Cüdde'de son bulur. Buradan Câr ve Medyen'e doğru ilerler ve Eyle'de son bulur.Burada Arap yurdunun Fars denizi ile olan sınırı sona erer. İşte burası Kulzum denizi ${ }^{18}$ denilen denizin başladığı yerdir. Târân ve Cübeylât'ta Kulzum sona erer. Bu sınır, Arap yurdunun doğusu, güneyi ve bir kısım batısıdır."19

Arap diyarında ağırlıklı olarak Mekke ve Medine'ye yoğunlaşan İstahrî bu şehirler ve mescidleri hakkında detaylı bilgi verir. Öncelikle Mekke ve Mescid-i Haram'ı anlatır: “Şehirleri anlatmaya Mekke'den başladık. Zira burayı Yüce Allah şerefli kılmıştır. Burası sarp dağlar arasında bir şehirdir.Ka'be de Mescid/ Mescid-i Haram'ın ortasındadır. Ka'be'nin kapısı yerden bir insan boyu yüksek ve tek parçadır. Kapılarıyla beraber Beyt'in/ Kâbe zemini yerden yüksektir. Ka'be'nin kapısı Zemzem kubbesininhizâsındadır’20

Detaylı bir Kâbe anlatımının ardından, Harem sınırları hakkında bilgi verir: "Arafat, Haram sınırlara dâhil değildir. Haram alanın sınırı Mâzimeyn'dir. Bu iki yeri geçince Alemeynel-Madrûbeyn'e gelirsin. Alemeyn'in arkası Haram'a dâhil değildir. Mescid-i Âişe olarak bilinen Ten'îm, Haram sınırlara dâhil değildir. Buranın aşağısı Haram sınırlara dâhildir. Haram sınırı yaklaşık 10 mil, ${ }^{21}$ yürüyerek bir gündür. Haram sınırlar belirlidir ve bu yönüyle diğerlerinden ayrılır."22

Medine'yi ağırlıklı olarak Mescid-i Nebevî eksenli olarak anlatır: "Mescid, hemen hemen şehrin ortasındadır. Hz. Peygamber'in mübarek kabirleri Mescid'in doğu tarafında, kıblenin yakınındadır. Burası Mescid'in doğu duvarıdır. Kabrin bulunduğu yer, yüksek bir evdir. Burası ile Mescid'in çatısı arasında bir yarıktan başka bir şey yoktur. İçerisinde Hz.

\footnotetext{
${ }^{17}$ İstahrî, Mesâlik, s. 12.

${ }^{18}$ Kulzumdenizi ile kastedilen Kizıldeniz'dir.

19 İstahrî, Mesâlik, ss. 12-13.

${ }^{20}$ İstahrî, Mesâlik, s. 15.

${ }^{21}$ Mil, yaklaşık olarak 1.5 km/ 1.500 m. Karşılığı olan bir uzunluk ölçüsüdür.

22 İstahrî, Mesâlik, s. 17.
} 
Peygamber, Hz. Ebûbekir ${ }^{23}$ ve Hz. Ömer' in ${ }^{24}$ mezarlarının bulunduğu kapısı olmayan, kapalı bir mekândır. Burada bir de daha sonra bir başka minber ${ }^{25}$ ile örtülen, Hz. Peygamber'in üzerinde hutbe verdiği minber vardır. Ravda, ${ }^{26}$ minberin önündedir; aralarında Hz. Peygamber'in Kabr-i Şerîfleri vardır.,"27

İlerleyen pasajlarda, Yemâme, Bahreyn, Taif, Hicr, Tebük, Medyen, Hayber, Yenbu' ve Yemen hakkında bilgiler veren İstahrî bu bölgelerde yaşayan Arap kabilelerinden de bahseder $^{28}$ ve bu ilk bölge ile ilgili bilgileri mesâfeleri vererek bitirir. ${ }^{29}$

\section{Fars Denizi}

Günümüzde Hint Okyanusu olarak bildiğimiz Fars denizi, İstahrî’nin 2. başlığıdır. Öncelikle Fars denizinin sınırları hakkında bilgi verir: "Bu deniz Arap yurdu ile diğer İslâm ülkelerinin çoğunu birbirine birleştirir. Bir haritasını çizip kıyılarında bulunan yerlerden bahsedeceğim. Kenarında bulunan Kulzum denizinden başlayalım; doğu tarafına düşer veEyle'de son bulur. Detaylarıyla anlattı̆̆ımız şekilde, Abbâdân'a varmadan önce Arap yurdunu çepeçevre kuşatır. Daha sonra Dicle topraklarını izler Mehrûbân sahilinde son bulur. Oradan Cennâbâ'ya varır. Basra körfezini geçer ve Siraf'a ulaşır. Kirmân'ın arka tarafındaki Hürmüz sahillerine varır. Oradan Deybul'a ve Sind sahili olan Multân'a kadar ilerler. Böylelikle İslâm ülkelerinin sahilleri bitmiş olur. Bundan sonra Hind sahilleri başlar. Ardından Tibet sahilleri gelir. Oradan Çinsahillerine ulaşılır., 30

Târân, Eyle, Abbadân ve Sîrâf bu deniz kıyısında bahsini ettiği yerlerden bazılarıdır. ${ }^{31}$

\section{Magrib Yurdu}

İstahrî, 3. olarak Akdeniz'in batı ucunda bulunan Magrib’i ele alır: "Magrib, iki bölümdür. Bir yarısı doğuda, diğer yarısı batıda olmak üzere Rum denizi kıyılarında uzanır. Doğusu, Berka, Ifrîkiyye, Tâhert, Tanca, Sûs, Zîle ve buralara yakın olan topraklardır. Batısı

\footnotetext{
${ }^{23}$ Hz. Ebubekir, Ebû Bekr Abdullāh b. Ebî Kuhâfe Osmân b. Âmir el-Kureşî et-Teymîdir. (ö. 13/634) İlk müslümanlardan, Hulefâ-yi Râşidîn'in birincisidir. Bkz.: Mustafa Fayda, "Ebû Bekir", DİA, C.: 10, s. 101 vd.

${ }^{24}$ Hz. Ömer, Ebû Hafs Ömer b. el-Hattâb b. Nüfeyl b. Abdiluzzâ el-Kureşî el-Adevîdir. (ö. 23/644) Hulefâ-yi Râşidîn' in ikincisi (634-644) Bkz.: Mustafa Fayda, “Ömer”, DIAA, C.: 34, ss. 44-51.

${ }^{25}$ Minber, camilerde cuma ve bayram namazlarında hatibin üzerine çıkarak hutbe okuduğu basamaklı mimari unsurdur. Bkz.: Nebi Bozkurt, "Minber", DIA, C.: 30, s. 101 vd.

${ }^{26}$ Ravda, Mescid-i Nebevî içinde Hz. Peygamber'in kabri ile minberi arasındaki bölümdür. Bkz. Nebi Bozkurt, "Ravza-i Mutahhara", "DİA, C.: 34, s. 475.

27 İstahrî, Mesâlik, s. 18.

${ }^{28}$ İstahrî, Mesâlik, ss. 18-26.

${ }^{29}$ İstahrî, Mesâlik, ss. 27-28.

${ }^{30}$ İstahrî, Mesâlik, ss. 28-29.

${ }^{31}$ İstahrî, Mesâlik, ss. 31-36.
} 
Endülüs'tür; fakat ben her ikisini tek bir başlık altında topladım.Doğu yönü, Berka ve İskenderiye arasından Misır'a sınırdır., 32

Endülüs, Berka, Mehdiye, Tûnis, Taberka, Tenes, Nâkûr, Ezîle, Basra, Tanca, Sicilmâsa, Satîf ve Kayrevan ile Endülüs'teki Ceyyân, Tuleytula, Sarakusta, Lâride, Vâdi'lHicâra,Turcâle, Kûriye, Mâride, Bâce, Gâfik, Leble, Karmûne, Mevrûr, İstice ve Reyye bu bölümde konu edindiği şehirlerdir. ${ }^{33}$

Endülüs ve Magrib'deki Berberlerden bahseden İstahrî, onlar hakkında "Berberler iki sınıftır. Bu sınıflardan birine Butra, diğerine Berânis denir. Nefze, Muknâse, Hevvâre ve Medyûne Butra'dandır ve Endülüste bulunurlar. Kutâme, Zenâte, Masmûde, Melîle ve Sinhâce Berânis'tendir. Zenâte'nin asıl vatanı Tâhert civarıdır. Kutâme'nin asıl vatanı Satîh civarıdır. Berânisten olan diğer Berberler, Rum denizinin doğu kıyılarında dağınık haldedirler. Nefze ve Muknâse, Endülüs'te, Celâlika ile Kurtuba şehri arasındadır. Hevvâre ve Medyûne, Şantaberiye' de yerleşiktir." bilgisini verir. ${ }^{34}$

Son olarak, Magrib' deki mesâfeleri vererek bu başlık altındaki bilgileri tamamlar. ${ }^{35}$

\section{Misir Yurdu}

İstahrî, Magrib'den sonra Mısır yurdu hakkında bilgi verir. Bilgilerine Mısır sınırlarını vererek başlar: “Mısır'ın sınırı Berka ile İskenderiye arasında bulunan Rum denizi kıyılarından başlar. Karayı takibederek vahâların ardına kadar varır, sonra Nûbe ülkesine uzanır. Nûbe sınırlarından geçerek Bucce sınırında bulunan Usvân'a ulaşır. Usvân'ın arka taraflarından Kulzum denizine varır. Kulzum denizi kıyılarında ilerler, Kulzum'u geçer ve deniz kıyısında bulunan Tûr-i Sînâ'ya ${ }^{36}$ varır. Buradan Tîh-i Benî İsrâîl'e doğru kıvrılır ve Rum denizine ulaşır. Buradan İskenderiye'ye gelir ve böylelikle bahsettiğimiz başlangıç noktasına gelmiş olur."37

Daha sonra Mısır' daki mesâfeleri veren İstahrî, ${ }^{38}$ Feyyûm, Usvân, Saîd, İskenderiye ve Fustat şehirlerinden bahseder ve konuyu tamamlar. ${ }^{39}$

\footnotetext{
32 İstahrî, Mesâlik, s. 37.

${ }^{33}$ İstahrî, Mesâlik, ss. 37-42.

${ }^{34}$ İstahrî, Mesâlik, s. 44.

${ }^{35}$ İstahrî, Mesâlik, ss. 46-48.

${ }^{36}$ Cebel-i Tûr-i Sina, Hz. Mûsâ'ya Tevrat'ın verildiği dağdır. Aynı adı taşıyan yarımadanın güneyinde bulunan dağla özdeşleştirilen Sînâ, Yahudi, Hıristiyan ve İslâm geleneklerinde Hz. Mûsâ'ya Tevrat'ın verildiği yer olarak kabul edilir. Bkz.: Mustafa Sinanoğlu, "Sînâ", DİA, C.: 37, s. 221.

${ }^{37}$ İstahrî, Mesâlik, s. 48.

${ }^{38}$ İstahrî, Mesâlik, s. 48.

${ }^{39}$ İstahrî, Mesâlik, ss. 49-55.
} 


\section{5. Şam Toprakları}

İstahrî, Şam topraklarını anlatmaya sınırlarından başlar: "Şam’ın batısı Rum denizi, doğusu Eyle'den Fırat'a kadar kırsaldır. Fırat'tan itibaren Rum denizidir. Kuzeyi Rum ülkesidir. Güneyi Mısır ve Tîh-i Benî İsrail'dir. Diğer bir sınırı Mısır tarafında Refah, Rum tarafında sugûrlardır. Bu sugûrlar şunlardır: Malatya, Hades, Mar'aş, Hârûniye, Kenîse, Ayn Zerba, Missîsa, Ezene ve Tarsus'tur." ${ }^{40}$

Şam'1 cündlere ayıran müellif, buraları “Cündü Filistin, ${ }^{41}$ Cündü Ürdün, Cündü Hıms, Cündü Dımaşk, Cündü Kınnesrîn, Avâsım ${ }^{42}$ ve Sugûr" olarak belirler ${ }^{43}$ ve bu cündleri detaylı olarak anlatır. Örneğin, Cündü Filistin'i anlatırken, “batı yönünde Şam’ın ilk cündüdür. Binitli birisi için uzunluğu Refah'tan Leccûn sınırına kadar 2 günlük, genişliği Yafa'dan Rîhâ'ya kadar 2 günlük mesâfedir. Zugar, Lût kavminin ${ }^{44}$ yurdudur; Cibâl ve Şarât buraya bağlıdır. Eyle arazisi, Lût kavmi yurdu, Muntanna gölü ve Zugar'dan, Beysan, Taberiye, iki dağ arasında kalan Gavr ve diğer Şam ülkesine kadar olan yerlerdir. Topraklarının bir kısmı Filistin, bir kısmı da Ürdün topraklarından yüksektedir. Filistin'in kendisi aşağıda anlatacağım gibidir. Su ihtiyacı yağmur sularından giderilir. Nâbulus haricinde tarımı ve ağaçları ile sağlıklı bir yerdir. Nâbulus'ta akarsular vardır. Filistin, Şam ülkesinin en güzel yeridir. En büyük şehri Remle'dir. Ardından Beytü'l-Mukaddes gelir. Beytü'l-Mukaddes, sırtını dağa yaslamış yüksek bir şehirdir. Filistin'den herkes buraya uğrar. İslâm dünyasında

\footnotetext{
${ }^{40}$ İstahrî, Mesâlik, s. 55.

${ }^{41}$ Hz. Ebû Bekir tarafından Irak ve Suriye cephelerinde başlatılan fetih hareketi kısa sürede genişledi. Hz. Ömer zamanında Irak ve İran'ın büyük bir kısmıyla Suriye, Ürdün, Filistin, el-Cezîre bölgesi ve Mısır fethedildi. Hz. Ömer, halifelik merkezinden uzak olan bu bölgelerde asayişi ve fetihlerin devamını sağlayabilmek için Basra, Kûfe ve Fustat gibi ordugâh şehirler kurdurdu. Bu şehirlere ve Suriye'de Dımaşk, Filistin'de Remle, Mısır'da İskenderiye gibi merkezlere çeşitli Arap kabilelerine mensup askerleri aileleriyle birlikte yerleştirip buraları dâimî ordugâh (garnizon) haline getirdi. Bkz.: Mustafa Zeki Terzi, "Ordu”, DİA, C.: 33, s. 357 vd.

42 Avâsım, İslâm devletleriyle Bizans İmparatorluğu arasındaki müstahkem sınır bölgelerine verilen addır. Avâsım sözlükte "korumak, engel olmak; sığınmak" anlamındaki asm (عصم ) kökünden türeyen âsımenin çoğulu olup "koruyanlar, müstahkem mevkiler" demektir. Bu müstahkem mevkiler, İslâm ordularının cihad maksadıyla sınırdan uzaklaştıkları zaman veya gazâdan dönerken ülkeye girmeden önce düşman saldırılarına karşı sığınıp korundukları bölgeler olduğu için bu adla anılmıştır. Bkz.: Hakkı Dursun Yıldız, "Avâsım”, DİA, C.: 4, ss. 111112.

${ }^{43}$ İstahrî, Mesâlik, s. 56.

${ }^{44}$ Lût, Kur'an'da adı geçen bir peygamberdir. Tevrat'ta Terah'ın çocuklarından Haran'ın oğlu ve İbrâhim'in yeğeni olarak gösterilir. İslâm öncesi Arap toplumunda bilinmeyen lût kelimesinin İbrânîce veya Süryânîce olduğu ileri sürülmektedir.Kur'ân-1 Kerîm'de yirmi yedi yerde ismen zikredilen Lût'un İbrâhim'in tebliğini kabul ettiği (Ankebût 29/26), onunla birlikte bereketli ülkeye ulaştırıldığı (Enbiyâ 21/71), peygamberlerden olduğu (Sâffât 37/133), diğer peygamberler gibi âlemlere üstün kılındığı (En‘âm 6/86), ona hüküm ve ilim verildiği, sâlihlerden olduğu ve ilâhî rahmete kabul edildiği (Enbiyâ 21/74-75) bildirilmektedir. Kavmine Allah'a karşı gelmekten sakınmalarını, kendisine itaat etmelerini, kadınlar yerine erkeklerle beraber olmalarının büyük ahlâksızlık ve günah olduğunu bildirmiş, bundan vazgeçmelerini istemiştir. Kavmi ise işlerine karışmaya devam ettiği takdirde sürgün edileceğini söylediği gibi, "Eğer doğru söylüyorsan bizi tehdit ettiğin azabı getir" diye kendisine meydan okumuştur. Bunun üzerine Lût onların yaptıklarının vebalinden kendini kurtarması için Allah'a dua etmiştir (A'râf 7/80-81; Şuarâ 26/160-166; Neml 27/54-55; Ankebût 29/28-30). Bkz.: Ömer Faruk Harman, "Lût”, DİA, C.: 27, ss. 227-229.
} 
benzeri büyüklükte başka bir mescidin bulunmadığı bir mescidi ${ }^{45}$ vardır. Bina mescidin batı köşesindedir. Mescid alanının hemen hemen yarısını kaplar.” bilgilerini verir. ${ }^{46}$ Nâbulus, Cibâl ve Şarât ve Sûr bu bölgede ele aldığı diğer şehirlerdir. ${ }^{47}$

Şam topraklarında Cündü Dımaşk’a önem verir. Zira, Dımaşk bu toprakların en önemli şehridir: "Dımaşk, Şam topraklarındaki en görkemli şehirdir. Etrafını çeviren dağlar arasındaki geniş arazide kuruludur. Tarımı, ağaçları ve suları boldur. Gûta denilen ve 1 merhaleye 2 merhalelik bir alana sahip olan yere bitişiktir. Batı yönünde buradan daha nezih bir yer yoktur. Suyu Fîce denilen bir kilisenin altından gelir."48

Ba'lebekke,Etrâbulus, Antartus,Selemye,Şeyzer ve Hama,Ma'arratu'n-Nu'mân, Bâlis,Menbic,Sümeysat,Malatya,Hısn-1 Mansûr,Zabatra,Hunâsıra, Hârûniye, İskenderûne, Bayyâs, Kenîse, Ayn Zerba, Missîsa, Ezene, Tarsus, Evlâs, Rakîm, Havrân ve Beseniye, Bagrâs ve Beyrut bu bölgede ele aldığı şehirlerden bir kaçıdır. ${ }^{49}$ Istahrî, mesâfeleri vererek bu bölge ile ilgili bilgileri tamamlar. ${ }^{50}$

\section{Rum Denizi}

Rum denizi, Mesâlikü'l-Memâlik'te anlatılan 3 denizden bir diğeridir. Bu denizi 'Rum denizi, Okyanusun bir körfezidir. Endülüs ile Tanca ülkesindeki Basra ve Tanca ile Cezîretü Cebel-i Târık arasıdır. ${ }^{51 "}$ şeklinde vasıflar. ${ }^{52}$ Sınırlarını, "Doğu yönünde Magrib sahillerini izler ve Mısır topraklarına kadar ulaşır. Mısır arazisini geçtikten sonra Şam arazisine kadar ilerler. Burada Sugûr'a doğru kıvrılır. Antakya yakınlarında Rum ülkesi topraklarına doğru döner ve batı yönünde Konstantiniyye körfezine ${ }^{53}$ ulaşır. Buradan dönerek Esînâs/ Atina sahilinden ilerlemeye devam eder. Rum sahillerini izleyerek Efrenc yakınlarında bu denizin güney kesimlerine ulaşır. Bu yöndeki kıyıları Efrenc'dir. Daha sonra Endülüs topraklarında bulunan Tartûşa'ya ulaşır. Böylelikle daha önce Endülüs bahsinde anlattı̆̆ımız ülkelere gelir. Burası Cezîretü Cebel-i Târık hizâsındadır.” olarak belirler. ${ }^{54}$

\footnotetext{
${ }^{45}$ Burada mescid ile kastedilen haram bölgedir.

${ }^{46}$ İstahrî, Mesâlik, s. 56.

${ }^{47}$ İstahrî, Mesâlik, ss. 57-59.

${ }^{48}$ Istahrî, Mesâlik, s. 59.

${ }^{49}$ İstahrî, Mesâlik, ss. 61-66.

${ }^{50}$ İstahrî, Mesâlik, ss. 66-68.

${ }^{51} \mathrm{Bu}$ ifadelerle Rum denizinin okyanustan ayrıldı̆̆ı, günümüzde Cebelitarık Boğazı olarak bildiğimiz bölge tanımlanmaktadir.

${ }^{52}$ İstahrî, Mesâlik, s. 68.

${ }^{53}$ Konstantiniyye körfezi ile Marmara denizi kastedilmektedir.

${ }^{54}$ İstahrî, Mesâlik, s. 69.
} 
Antâliye,Esînâs/ Atina ve Rûmiyye/ Roma bu bölgede bahsettiği sahillerdir. Ayrıca Rum denizinde bulunan Sicilya/ Sıkıliyye, Girit/ İkrîtiş, Kıbrıs/ Kubrus ve Cebelü'l-Kalâl ${ }^{55}$ adaları hakkında bilgi verir.Örneğin Sicilya/ Sıkıliyye adasını, "Efrenc yakınlarındadır. Buradan Efrenc toprakları görülebilir. Arazilerinde ekim-dikim yapılır. Uzunluğu yaklaşık 7 merhaledir. Sicilya'nın/ Sıkıliyye arazisi geniş, bereketli ve tarıma elverişlidir. Hayvancılık ve köle ticareti burada çokça yapılan işlerdir. Burası pek çok İslâm memleketine göre denizde sınırdır ve tercih edilen bir yerdir." şeklinde anlatır. ${ }^{56}$

\section{7. el-Cezîre Toprakları}

İstahrî, el-Cezîre'yi şuşekilde tanımlar: "Dicle ve Fırat arasıdır. Rebî'a ${ }^{57}$ ve Mudar" yurtlarından oluşur. Fırat'ın çıkış yeri Rum ülkesinde Malatya'ya 2 günlük bir mesâfededir. Malatya ile Sümeysat arasından geçer ve Sümeysat, Cisr-i Menbic, Bâlis, Karkîsiye, Rahbe, Hît ve Enbâr'a kadar ilerler. Burada el-Cezîre'nın sınırına gelir. Kuzey yönünde, el-Cezîre sınırından Tikrît'e doğru döner. Tikrît, Dicle kıyısındadır. Buradan itibaren Sinnü'ye akar. Dicle, el-Cezîre, Hadîse, Musul, Cezîretü İbn Ömer/Cizre üzerinden gelir; daha sonra Âmid

\footnotetext{
${ }^{55}$ Muhtemelen Korsika ve Sardunya adaları kastediliyor. Zira Akdeniz' de Kıbrıs, Girit ve Sicilya dışında büyük olarak bu 2 ada bulunmaktadir.

${ }^{56}$ İstahrî, Mesâlik, s. 70.

${ }^{57}$ Benî Rebîa, Araplar'ın dört ana kolundan birisidir. Kabilenin ceddi Rebîa'nın soyu babası Nizâr b. Mead vasitasıyla Adnân'a ulaşır. Adnân ve Kahtân'dan sonra Araplar'ın nisbet edildiği dört ana koldan biri olan Rebîa'nın (diğerleri Mudar, Kudâa ve Yemen) Esed, Tağlib, Vâil, Bekr, Şeybân, Hanîfe, Abdülkays, Kāsıt ve Ahmes gibi birçok kolu bulunmaktadır. Nizâr'ın çocukları Arabistan'a dağıldığında Rebîa, Gamrızîkinde denilen dağın eteklerine, Necid'deki Zâtüırk adlı bölgeye ve Tihâme'nin aşağı bölgelerine gidip yerleşti. Kardeşleri İyâd'ın ayrılmasından sonra Tihâme'de sadece Rebîa ve Mudar kaldı. Nüfusları artıp bölge kendilerine dar gelmeye başlayınca Rebîa, Necid ve Tihâme bölgesinin iç kesimlerine yöneldi; bu yayılma süreci Arap yarımadası dışına taşarak İslâm döneminde de devam etti. Kabile mensupları Emevîler ve Abbâsîler döneminde Kûfe, Basra ve Kayrevan gibi yeni şehirlerde yerleşip mahalleler kurdu. Kaynaklarda geçen Diyârırebîa, Arap yarımadasının kuzeyinde Musul'dan Fırat havzasına kadar uzanan Musul, Nusaybin, Sincar ve Cizre gibi yerleşim yerlerinin bulunduğu bölgeyi ifade etmektedir. Bu bölge Rebîa'nın büyük kollarından Vâil, Bekr ve Tağlib'in yurduydu. Wellhausen, Emevîler döneminde Rebîa denildiğinde bu kabilenin kollarından Bekir b. Vâil oğullarının kastedildiğini belirtir. Sürekli genişlemekten dolayı kabile içerisinde zamanla anlaşmazlıklar ortaya çıktı; Benî Âmir b. Hâris ile Benî Abdülkays arasındaki çekişme iç savaşa yol açtı. İç savaş sonrasında Rebîa’nın diğer bazı kolları Necid, Hicaz ve Yemen'in çeşitli bölgelerine dağıldılar. Benî Abdülkays Bahreyn'e gidip yerleşti; Bekr, Tağlib, Aneze ve Dubey'a kabileleri Necid, Hicaz ve Tihâme’ de yayıldı. Kabilenin bazı kolları da Misır'a gitti. Bkz.: İrfan Aycan, "Rebîa(Benî Rebîa)", DİA, C.: 34, s. 498 vd.

${ }^{58}$ Benî Mudar, Araplar'ın dört ana kolundan birisidir. Kabilenin ceddi Mudar, Nizâr b. Mead b. Adnân'ın oğludur; "Hamrâ" (kırmızı) lakabıyla da bilinir; kırmızı aynı zamanda Mudaroğulları'nın bayrak ve sarıklarında kullandıkları renktir. Adnân ve Kahtân'dan sonra Araplar'ın kendilerine nisbet edildikleri dört ana koldan biri olan Mudar (diğerleri Rebîa, Kudâa ve Yemen), İslâmiyet'ten önce Hındif ve Kays Aylân adında iki kola ayrıldı. Sayı ve güç itibariyle çok defa bütün Mudar kabilelerini temsil eden Kays Aylân'ın en meşhur kolları Süleym, Hevâzin, Mâzin, Gatafân, Muhârib, Advân, Fehm ve Enmâr; Hındif'in kolları ise Kureyş, Eşrâf, Kinâne, Hüzeyl, Temîm, Huzâa ve Müzeyne'dir. Mudar'ın ana yurdu olarak Saravât'a kadar Mekke Haremi'nin sınırlarıyla Gavr ve çevresi kaydedilir. Rebîa ile ittifak yapan Mudar, Mead ve kollarını Mekke ve çevresinden çıkarıp yurdunu genişletti. Rebîa'ya üstünlük sağlayan Mudar'ın en önemli kolu Kureyş Mekke'de kalırken diğerleri Arap yarımadasının çeşitli bölgelerine dağıldılar. IV. yüzyılın başından itibaren Arabistan dışına çıkarak Harran, Rakka, Şimşât, Tellümevzen ve Suruç dolaylarına kadar yayıldılar. Bkz.: Mustafa Sabri Küçükaşçı, "Mudar(Benî Mudar)", DİA, C.: 30, s. 358 vd.
} 
civarından geçer. Dicle, İrmeniye sınırının bir bölümünden başlar. Sonra batıya doğru ilerler ve Sümeysat'a varır. Burası İslâm sınırlarında, Fırat sularının çıktığı yerdir. Biz de konuyu anlatmaya buradan başladık. Dicle'nin çıkış yeri Âmid'in üst tarafında İrmen sınırındadır. Dicle'nin doğusunda ve Fırat'ın batısında kalan şehirler ve köyler el-Cezîre'den sayılır. Aşağı yukarı bu şekildedir., ${ }^{, 59}$

Daha sonra bölgedeki mesâfeleri veren İstahrî, ${ }^{60}$ Musul, Beled, Sincar, Dârâ, Kefertûsa, Ra'sü'l-Ayn, Âmid, Cezîretü İbn Ömer/Cizre, Şimşât, Hadîse, Sinnü, Harran, Ruhâ, Cisr-i Menbic, Sümeysat, Karkîsiyâ, Tikrît ve Serûc'u anlatarak bölge ile ilgili bilgilerini tamamlar. ${ }^{61}$

\section{Irak}

Irak'1 anlatmaya, diğer bölgelerde olduğu şekliyle sınırlarını vererek başlar: “Basra'nın arka taraflarından Sevâdü'l-Basra kırsalına ve bataklıklarına, Vâsıt'a, Sevâdü'lKûfe kırsalına ve bataklıklarına, Fırat'ın arka taraflarından Enbâr'a, Enbâr'dan Dicle ve Fırat arasındaki Tikrit'e varır. Bu şekilde denizden Tikrit'e doğru yine bir yay gibi kıvrılır. İște bu geniş alan Irak'tır.",62

Daha sonra Irak'taki mesâfeleri verir ve Basra,Übülle, Vâsit, Kûfe, Kâdisiye, Hîre, Havernak, Bağdâd, Sâmerrâ, Medâyin ve Bâbil bu bölgede anlattığı başlıca şehirlerdir. ${ }^{63} \mathrm{Bu}$ şehirler içerisinde Bağdâd, Basra, Kûfe ve Sâmarra'ya ayrı bir önem gösterir. Zira bu şehirler İslâm toplumunun kurduğu şehirlerdir. Örneğin, Basra'yı anlatırken şöyle der: "Basra, büyük bir şehirdir. Acemler döneminde ${ }^{64}$ bu şehir yoktu. Burayı Ömer b. el-Hattâb zamanında Müslümanlar kurdu. Şehri kuran, kabileleri yerleştiren ve sokaklarını oluşturan kişi Utbe b. Gazvân'dır. ${ }^{65}$

Benzer şekilde Bağdâd ile ilgili şu bilgileri verir: "Bağdâd, sonradan İslâm döneminde kurulmuş bir şehirdir. Daha önceleri buralarda bir yapılaşma yoktu. Mansur ${ }^{66}$ bat1 yönünde bir

\footnotetext{
${ }^{59}$ İstahrî, Mesâlik, ss. 71-72.

${ }^{60}$ İstahrî, Mesâlik, s. 72.

${ }^{61}$ İstahrî, Mesâlik, ss. 73-78.

${ }^{62}$ İstahrî, Mesâlik, s. 79.

${ }^{63}$ İstahrî, Mesâlik, ss. 80-87.

${ }^{64}$ Acemlerdönemi ile İslâm öncesi dönem kastedilmektedir.

65 Utbe b. Gazvân, Ebû Abdillâh (Ebû Gazvân) Utbe b. Gazvân b. Câbir el-Mâzinîdir. (ö. 17/638) İlk müslümanlardan, Basra şehrinin kurucusudur. Bkz.: Erdinç Ahatlı, "Utbe b. Gazvân”, DİA, C.: 42, s. 235

${ }^{66}$ Mansur, Ebû Ca'fer el-Mansûr Abdullāh b. Muhammed b. Alî el-Hâşimî el-Abbâsîdir. (ö. 158/775) H. 136158/ M. 754-775 tarihleri arasında hilâfet makamında oturan Abbâsî halifesidir. Bkz.: Nahide Bozkurt, "Mansur", DIA, C.: 28, ss. 5-6.
} 
şehir kurdu. Şehri, mevâlîsi ${ }^{67}$ ve kendisine tâbi olanları için Rebî' iktâ'sı, Harbiye iktâ'sı ve diğerleri gibi iktâ'lara böldü.. Daha sonra da burayı bayındır/ mamur hale getirdi. Mehdî ${ }^{68}$ döneminde şehrin batı tarafı, Mu'askerü'l-Mehdî adıyla bir garnizon haline getirildi."69

\section{Huzistan}

Huzistan'ın sınırları şu şekildedir: “Doğusu Fars sınırı ve Isfahân'dır. Fars sınırı ile arasında, Isfahân sınırından itibaren Tâb nehri bulunur. Burası Mehrûbân yakınlarındaki sınırdır. Daha sonra bu yönde sınır, denizin arka taraflarında Mehrûbân ve Devrek arasından geçer. Batısı Vâsıt yerleşimleri ile Duveru'r-Râsebî'dir. Kuzeyi Saymera, Kerhâ ve Lûr sınırıdır. Bu yönde sınır Cibâl sınırlarına ve Isfahân'a kadar ulaşır. Huzistân'ın sınırı, Fars ve Isfahân'dan başlayıp Cibâl sınırlarını ve Vâsıt'ı geçerek düz bir istikamette kare şeklindedir. Sadece güney sınırı Abbadân'dan Vâsıt yerleşimlerine doğru koni şeklindedir.” ifadeleriyle belirler. $^{70}$

Daha sonra bölgenin tarımı hakkında bilgi veren İstahrî, şöyle der: "Huzistân arazisinde çoğunlukla hurma ağacına rastlanır. Güney kesimlerinde buğday, arpa ve baklagiller üretilir. Güney kesiminde buğday ve arpadan sonra pirinç gelir; bunun ekmeğini yaparlar. Bu ekmek onlar için güç ve kuvvet demektir. Bu durum Irak’taki yerleşim yerlerinde de bu şekildedir. Buradaki büyük yerleşim yerleri/ kuveru'l-kibâr dışında şeker kamışı üretilen başka yer yoktur. Fakat şeker kamışı üretiminin çoğu Mesrukân’dadır. Buradan Askeri Mukram'a götürülür. Askeri Mukram'da şeker kamışı çok değildir. Tüster ve Sûs da aynı şekildedir. Bu iki yer de şeker kamışını Mesrukân'dan temin eder. Burada ceviz dışında bütün meyveleri bulmak mümkündür. Ceviz Sarûd/ Soğuk İklim ${ }^{71}$ ülkeleri dışında olmaz.”,72

Huzistân bölgesi ile birlikte İstahrî, bölgelerin folklorik özellikleri hakkında bilgi vermeye başlar: "Genel olarak Arapça ve Farsça konuşurlar. Hûzî dili denilen bir başka dilleri vardır. Bu dil ne İbrâniceye ne Süryâniceye ve ne de Farsçaya benzer. Giysileri Irak halkının giysileri gibidir. Gömlek, omuz örtüsü ve sarıktan oluşur. Üzerlerine îzâr/ önlük giyerler.

\footnotetext{
${ }^{67}$ Mevâlı̂, Arap olmayan Müslüman halklar için kullanılan bir terimdir. Bkz.: İsmail Yiğit, "Mevâlı̂”, DİA, C.: 29, s. 424.

68 Mehdî, Ebû Abdillâh Muhammed el-Mehdî-Billâh b. Abdillâh el-Mansûr b. Muhammed el-Hâşimî elAbbâsîdir. (ö. 169/785) H. 159-169/ M. 775-785 tarihleri arasında hilâfet makamında oturan Abbâsî halifesidir. Bkz.: Nahide Bozkurt, "Mehdî-Billâh", DIA, C.: 28, s. 378 vd.

${ }^{69}$ İstahrî, Mesâlik, s. 83.

${ }^{70}$ İstahrî, Mesâlik, s. 88.

${ }^{71}$ Bu ifade "Sarûd" ve "Cerûm" olarak değişik yerlerde geçmektedir. Metinde "Sarûd/ Soğuk İklim" ve "Cerûm/ Sıcakİklim" şeklinde kullandık. İstahrî, İran'1 anlattığı pasajlarda bu ifadeyi kendisi açıklamakta ve "Güney yönünde olan Cerûm, kuzey yönünde olan ise Sarûd'dur." demektedir. Bir başka deyişle Fars ülkesinin kuzey ve soğuk kesimlerini Sarûd, güney ve sicak kesimlerini Cerûm olarak nitelemektedir. Bkz.; İstahrî, s. 136.

${ }^{72}$ İstahrî, Mesâlik, s. 91.
} 
Yaratılışları huysuz bir tabiattır. Bazı işlerinde rekabetçilik ve şiddetli taraftarlık görülür. Solgun benizlidirler. İnce ve seyrek sakallıdırlar. Saçları gürdür. Şehirlerde bunların dışında özelliklere sahip olanlar azınlıktadır. İşte bunlar genel vücut özellikleridir. Farklı dinlere inanırlar. Huzistân'da sapkın mezhepler çoğunluktadır. Diğer medeniyet merkezlerinde olduğu gibi pek çok yerleşim yerinde/ kuver hak mezhepler mevcuttur."73

$\mathrm{Bu}$ bölgede başlayan bir başka başlık ise bölgeye has olaylardır/ hassiyyât. İlk 8 bölümde bu konuda bilgi vermeyen İstahrî, artık bu tarz bilgiler vermeye başlar: "Bana

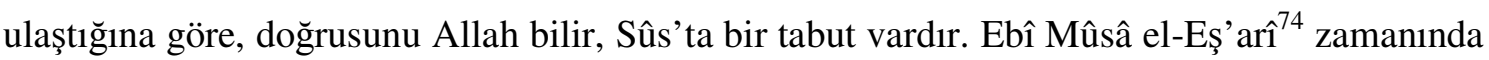
bulunmuştur. Söylenildiğine göre içerisinde Hz. Danyal'ın ${ }^{75}$ (as) kemikleri vardır. Ehl-i Kitâb, ${ }^{76}$ gruplar halinde etrafında döner, onu kutsar ve kendisinden yağmur yağdırmasını isterlerdi. Yağmur yağmayıp kuraklık olunca Ebû Mûsâ el-Eş’arî onu nehre götürdü ve Bâbu Sûs kenarına dikti. Böylelikle burada bir körfez oluştu. Bu körfezde/ halic tuğladan üç mezar yaptırdı. Söz konusu tabutu bu mezarlardan birine defnetti. Hepsini kapattı ve hangisinde olduğunu gizledi. Daha sonra nehrin suyu bu kabirlerin arkasına gelinceye dek suyun önünü açtı. Günümüze değin onların üzerlerinden su akar. Her kim suyun dibine varırsa, orada bu mezarları bulur."77

Tüster, Sûs, Râmhürmüz, Besinnâ, Tîb, Lûr, Senbîl ve Âsek bu bölgede bahsettiği başlıca şehirlerdir. ${ }^{78}$ Bölge ile ilgili bilgileri, mesâfeleri vererek tamamlar. ${ }^{79}$

\section{Fars Ülkesi}

Fars başlığı, İstahrî’nin eserinde temel gövdedir. Kendisinin de Farslı olması nedeniyle eserde en hacimli bölümü oluşturur. Fars bölgesinin anlatımı ile birlikte Mesâlikü'lMemâlik'teki konu çeşitliliği artar. Bölgeyi anlatmaya sınırlarını belirleyerek başlar: "Fars'ın doğu yönünde Kirmân vardır. Batısı, Huzistân yerleşimleri ve Isfahân'dır. Kuzeyinde Fars ve Horasân arasında bulunan ve bir kısım Isfahân topraklarını da kapsayan çöl yer alır. Güneyi

\footnotetext{
${ }^{73}$ İstahrî, Mesâlik, s. 91.

${ }^{74}$ Ebî Mûsâ el-Eş’arî, Ebû Mûsâ Abdullah b. Kays b. Süleym el-Eş‘arîdir. (ö. 42/662-63) Hakem Vak'ası'nda Hz. Ali' yi temsil eden fakih sahâbîdir. Bkz.: M. Yaşar Kandemir, "Ebû Mûsâ el-Eş’arî”, DİA, C.: 10, s. 190 vd.

${ }^{75}$ Danyal, Kitâb-1 Mukaddes'e göre Benî İsrâil peygamberlerinden olan kutsal kitap yazarlarından birisidir. Ahdi Atîk'te adı Dânî̂l (Daniel, 1/6-8) olarak geçmektedir. Ahd-i Atîk'te bir başka Dânî̂l daha zikredilmektedir ki (Hezekiel, 14/14, 20; 28/3) onun kutsal kitap yazarıla ilgisi yoktur. Muhtemelen bu ikincisi, Ugarit metinlerinde nakledilen Fenike geleneğinin meşhur salih ve bilge kişisidir (Ancien Testament, s. 1027). Dânyâl İbrânîce'de "Tanrı hükmetti" (NDB, s. 167) veya "Benim hakîmim (savunucum) Tanrı' dır" (DB, II/2, s. 1247) anlamına gelmektedir. Daha geniş bilgi için bkz.: Ömer Faruk Harman, "Danyal”, DİA, C.: 8, s. 480 vd.

${ }^{76}$ Ehl-i Kitâb, Kur'ân-1 Kerîm'de genellikle Yahudiler ve Hıristiyanlar için kullanılan tabirdir. Bkz.: Remzi Kaya, "Ehl-i Kitap", DIA, C.: 10, s. 516 vd.

${ }^{77}$ İstahrî, Mesâlik, s. 92.

${ }^{78}$ İstahrî, Mesâlik, ss. 92-94.

${ }^{79}$ İstahrî, Mesâlik, s. 95.
} 
Fars denizidir. Sadece Isfahân yönüne düşen açı ile Kirmân'ın çöl yönüne düşen açısı hariç, Fars topraklarının haritadaki görüntüsü kareşeklindedir."

İstahrî, Fars'1 5 bölgeye/ kuver ayırarak anlatır:

- İstahr

- Erdeşîr Hurra

- Dârâbecird

- Errecân

- Sâbûr ${ }^{81}$

İstahrî, farklı toplumların yerleşim yerlerini anlattıktan ${ }^{82}$ sonra yerleşim yerlerini en küçükten büyüğe doğru, içerisinde minber olup olmadığına göre sıralar. ${ }^{83}$ Fars'ta bulunan kaleler, ateşevleri/ büyûtu nîrân, nehirler, denizler ve göller devamında anlattığı konulardır. ${ }^{84}$ İstahr,Sâbûr,Dârâbecird,Cûr,Şîrâz,Kârezîn,Eberkûh,Herat,Serdân,Beydâ,Errecân ve Nûbencân gibi şehirlerden bahseden ${ }^{85}$ İstahrî, konunun devamında Fars'taki mesâfeleri anlatir. $^{86}$

Fars bölgesi ile ilgili son bölüm, folklorik ağırlıklı bilgiler içerir. Fars'ın dili, giysileri, halkının özellikleri ve dinleri hakkında çok sayıda bilgi bulmak mümkündür. ${ }^{87}$ Örneğin dilleri hakkında "3 Farsça dili/lehçesi vardır. Fars halkının tamamı bu dillerden birini konuşur ama diğerlerinin ne demek istediğini anlar. ${ }^{88}$ Yazdıkları dil Acem'dir. Mecûsi dönemlerini, geçmişlerini, edebiyatlarını yazdıkları dilleri Pehlevicedir. Bu dil ile ilgili olarak herhangi bir açıklama ihtiyacı bulunmaz. Arapça ile saltanat ve divan yazışmaları yapılır.” bilgisini vermektedir. ${ }^{89}$

\footnotetext{
${ }^{80}$ İstahrî, Mesâlik, s. 96.

${ }^{81}$ İstahrî, Mesâlik, s. 97.

${ }^{82}$ İstahrî, Mesâlik, ss. 98-99.

${ }^{83}$ İstahrî, Mesâlik, ss. 101-115.

${ }^{84}$ İstahrî, Mesâlik, ss. 116-122.

${ }^{85}$ İstahrî, Mesâlik, ss. 123-129.

${ }^{86}$ İstahrî, Mesâlik, ss. 129-136.

${ }^{87}$ İstahrî, Mesâlik, ss. 137-139.

88 “Halk bu üç lehçeden birini kullanır" şeklinde anlaşılmalıdır.

${ }^{89}$ İstahrî, Mesâlik, s. 137.
} 
Fars bölgesinde verilen bir başka bilgi türü şahıslarla ilgilidir. İstahrî, bu bölgeyi anlatırken meşhur kişilerinden de bahsetmektedir. Selmân-1 Fârisî, ${ }^{90}$ Âl-i Saffâr, ${ }^{91}$ Abdullâh b. Mukaffa, ${ }^{92}$ Sibeveyh, ${ }^{93}$ Hallac-ı Mansur ${ }^{94}$ ve Hasan el-Cennâbî̀ ${ }^{95}$ bunlardan bazılarıdır. ${ }^{96}$

Bir önceki bölümde, Huzistân'1 anlatırken bahsettiği bölgeye has olaylar/ hassiyyâtkonusunda Fars ile ilgili daha geniş kapsamlı bilgiler aktarır: "İstahr'da, tasavvuru mümkün olmayan taştan binâlar, sütunlar ve binâ kalıntıları bulunur. Farslılar bu yapıların Hz. Süleyman (as) ve Hz. Dâvûd (as)'ın mescidi olduğunu söylerler. Burası cinlerin inşâ ettiği bir binâdır. Bu binâ benim Ba'lebekke, Şam toprakları ve Mısır'da gördüğüm o devâsâ yapılara benzer. Günümüzde bu binâların bir benzerini yapma imkânı yoktur."97 "Eberkûh yakınlarında külden tepeler vardır. Yöre halkı bu tepelerin Nemrûd b. Kenân'ın Hz. İbrahim'i (as) yakmak için kullandığı ateşin külleri olduğunu sanır. Ancak bu doğru değildir. Zira, Nemrûd Bâbil'de oturuyordu. Aynı şekilde Kenân kralları, Fars krallarından önce yaşamışlardı."98 "Kurân yöresinde pancar gibi yenilen bir çamur vardır. Bunun bir benzerine

\footnotetext{
90 Selmân-1 Fârisî, Ebû Abdillâh Selmân el-Fârisîdir. (ö. 36/656 [?])İslâmiyet'i kabul eden İran asıllı ilk sahâbîdir. Bkz.: İbrahim Hatiboğlu, "Selmân-1 Fârisî”, DİA, C.: 36, 441 vd.

91 Saffârîler, Doğu İran'da Sîstan bölgesinde hüküm süren bir İslâm hanedanıdır. (861-1003) Hânedanın kurucusu Ya'kūb b. Leys es-Saffâr, 247'de (861) Sîstan'a hâkim olduktan sonra doğuya doğru ilerleyerek hâkimiyet sahasını Gazne, Gerdiz ve Kabûl-Bâmiyân bölgesine kadar genişletti. Abbâsî Devleti'nin Kirman, Fars, Hûzistan ve Horasan'daki temsilcileriyle savaştı, Nîşâbur'u istilâ edip Tâhirîler'in buradaki idaresine son verdi (Şevval 259 / Ağustos 873). Bağdat'a 50 millik mesâfedeki Deyrülâkūl'da Abbâsî kuvvetlerine karşı hayatında ilk defa yenilen Ya'kūb (Receb 262 / Nisan 876), bu yenilginin intikamını almak için düzenleyeceği bir seferin hazırlıkları içindeyken öldü (14 Şevval 265 / 9 Haziran 879). Hânedanın kurucuları Ya'kūb ve Amr kültür ve sanata büyük önem vermişlerdir. Özellikle Amr, Şîraz'da bugün Mescid-i Câmi` adıyla anılan bir ulucamiden başka birçok cami, ribât, köprü, saray, çarşı, su kanalları ve çölde işaret taşları yaptırmış, Tâhir hazineleri yeni saraylar kurmak için harcamıştır. Diğer Saffârî emîrleri de IV. (X.) yüzyıl coğrafyacıları tarafından zikredilen birçok köprü ve yapı inşa ettirmişlerdir. Saffârîler yeni Fars edebiyatının oluşmasında da önemli rol oynamışlardır. Bkz.: Erdoğan Merçil, "Saffârîler", DİA, C.: 35, s. 464 vd.

92 Abdullâh b. Mukaffa, Ebû Muhammed (Ebû Amr) Abdullāh (Rûzbih / el-Mübârek) b. el-Mukaffa'dır (Dâdeveyh) (ö. 142/759) İran asıllı mütercim, edip ve kâtiptir. Bkz.: İsmail Durmuş, "İbnü’l-Mukaffa'”, DİA, C.: 21 , s. $130 \mathrm{vd}$.

93 Sibeveyh, Ebû Bişr (Ebû Osmân, Ebü'l-Hasen, Ebü’l-Hüseyn) Sîbeveyhi Amr b. Osmân b. Kanber elHârisîdir. (ö. 180/796) Arap dili gramerine dâir zamanımıza ulaşan ilk hacimli eserin yazarı ve Basra nahiv mektebinin en önemli temsilcisidir. Bkz.: M. Reşit Özbalıkçı, "Sibeveyhî”, DİA, C.: 37, s. 130 vd.

94 Hallâc-1 Mansûr, Ebü'l-Mugıs el-Hüseyn b. Mansûr el-Beyzâvîdir. (ö. 309/922) Tasavvufun gelişmesine önemli katkılarda bulunan ünlü mutasavvıftır. Bkz.: Süleyman Uludağ, "Hallâc-1 Mansûr", DİA, C.: 15, s. 377 vd.

95 Hasan el-Cennâbî, Ebû Saîd Hasen b. Behrâm el-Cennâbîdir. (ö. 301/913-14) Karmatîler'in güçlü reislerindendir. Bkz.: Mustafa Öz, "Cennâbî, Ebû Saîd”, DİA, C.: 7, s. 371.

${ }^{96}$ İstahrî, Mesâlik, ss. 140-149.

${ }^{97}$ İstahrî, Mesâlik, s. 150.

${ }^{98}$ İstahrî, Mesâlik, s. 151.
} 
herhangi bir yerde rastlamadım. Cennâbe'de denizde hârik denilen inci madeni vardır. Buranın incisi nadir bulunur ve daha üstünü yoktur. Dürretü'l-yetîme ${ }^{99}$ buradan elde edilir."100

Fars bölgesinde anlatılan bir diğer konu, ticaret mallarıdır. İstahrî, bundan sonraki bölümlerde de bu tarz anlatımlarını sürdürmüştür. Cûr'dan götürülen gül suyu, Sâbûr'dan yağ, Şînîz ve Cennâbâ, Kâzerûn ve Tevvec'den götürülen keten elbiseler, Fesâ'dan götürülen ve sultanlar için üretilen veşâ, şi'r ve sûsencerd tırâzları, Yezd ve Eberkûh'tangötürülen pamuk giysiler,Sirâf'tan götürülen deniz ürünleri, öd ağacı, anber, kâfûr, kıymetli madenler, fildişi, hayzurân, ${ }^{101}$ abanoz ve sandal ağaçları, baharât, biber ve şifalı bitkiler, divitler için siyah mürekkep bunlar arasındadır. ${ }^{102}$

$\mathrm{Bu}$ bölgenin son konusu, Fars'ın paraları, ağırlık ölçüleri ve vergilendirme sistemi üzerinedir. "Fars ülkesinde alışveriş dirhem iledir; ancak mallar dinar karşıllğı olarak sunulur."103 ifadeleriyle belirleyen İstahrî, devam satırlarında ağırlık ölçülerinden ve toprakların vergilendirme sisteminden bahseder:"Ağırlıklarından 10 dirhem 7 miskâldir. ${ }^{104}$ Yemen'de ve diğer yerlerde dirhemin ağırlığı değişmez. Malların tartılarında, menn, ${ }^{105}$ Şîrâz' da büyük ve küçük olmak üzere 2 çeşittir. Büyük 1.040 dirhemdir. ${ }^{106}$ Erdebil haricinde menni bu vezin üzere kullanan başka bir yer görmedim. Diğeri Bağdâd mennidir ve 260 dirhemdir. Bu men bütün Fars ülkesinde kullanılmaz. İslâm ülkelerinde de bundan başka bir ağırlığı kullanıldığını görmedim. Men, Beydâ' da 800 dirhem, İstahr'da 400 dirhem, Hurra'da

\footnotetext{
${ }^{99}$ Dürretü'l-yetîme, incilerin en kıymetlisi olarak kabul edilen türüdür.

${ }^{100}$ İstahrî, Mesâlik, s. 152.

${ }^{101}$ Hayzurân, bir tür Hint kamışıdır/ bambu.

${ }^{102}$ İstahrî, Mesâlik, ss. 152-155.

${ }^{103}$ İstahrî, Mesâlik, s. 156.

${ }^{104}$ Miskâl, eski bir ağırlık ölçüsü ve para birimidir. İslâm'dan önceki 14,16- gramlık İbrânî şekelleri / Grek staterleri, 8,5 gramlık İbrânî hafif şekelleri / Grek didrahmileri / Pers darikleri, 5,6- gramlık darik / siklos / sextula adındaki Pers gümüş denierleri, 4,72- ve 4,53- gramlık exaggion, sextans veya sextula da denen Roma altın solidusları, 4,25 gramlık Grek drahmileri / İbrânî hafif beka'ları vb. Araplar'ca miskal diye adlandırılmıştır. Bunlardan sonuncusu şer‘î ağırlık birimi miskal olarak kabul edilmiştir. Halife Abdülmelik'in bastırdığı İslâm'a has ilk altın sikkelerin (dinar) ağırlığı da 4,25 gr. geldiği için halk arasında miskal ve dinar kelimeleri dönüşümlü bir şekilde kullanılmıştır. Bkz.:Cengiz Kallek, "Miskâl”, DİA, C.: 30, s. 182 vd.

${ }^{105}$ Men, eski bir ölçü birimidir. Abbâsîler devrinde 260 dirhemlik Bağdat menni İslâm dünyasının hemen her yerinde kullanılan standart ağırlıklardandı. "Şer‘î men” olarak da anılan bu ölçü birimi için Hârizmî’ nin verdiği bilgilerden şu hassas eşitlik elde edilmektedir: 1 menâ $=2$ rıtl $=24$ ukıyye $=40$ istâr $=180$ miskal $=257 \mathrm{~d}$ dirhem. Metrik sistemdeki karşılığı ise 816 gramdır. Cengiz Kallek, "Men”, DİA, C.: 29, s. 105 vd.

${ }^{106}$ Dirhem, bir ağırlık ölçüsü ve gümüş para birimidir. İslâmî dirhemin teorik ağırlığı 2,97 gramdır (14 kırat). Ancak bunun biraz daha hafif ve ağırları da vardır. IX. yüzyılın üçüncü çeyreğine kadar bu ağırlıktan fazla uzaklaşılmamıştır. Bununla birlikte Vâsik-Billâh'ın hilâfetinden (842-847) itibaren tedavülde 3 gramdan daha ağır, hatta az da olsa 4-6 gr. arasında dirhemler darbedilmiştir. Halil Sahillioğlu, "Dirhem”, DİA, C.: 9, s. 368 vd.
} 
280 dirhem, Sâbûr'da 300 dirhem, Erdeşîr Hurra'nın bazı yörelerinde 240 dirhemdir."107

"Arazilerinden alınan haraç üç türlüdür:

- Yüzölçümüne/ mesâha göre,

- Bölümlendirmeye/ mukâseme göre,

- Kanunlara/ kavânîn göre.

Kanunlara/ kavânîn göre ister ekilsin, ister ekilmesin belirli ölçülerde araziler/ mukâtaâtün ma'rûfetün vardır ve bu araziler ne artar ne de eksilir. Yüzölçümüne/ mesâha ve bölümlendirmeye/ mukâseme göre alınacak haraç şöyledir: Eğer arazi ekilmişse haraç alınır, ekilmemişse alınmaz." 108

\section{Kirmân Ülkesi}

Kirmân'ın sınırlarını belirleyen ve burayı 2 farklı bölge olarak değerlendiren İstahrî, şu ifadelere yer verir: “Kirmân'ın doğusu Mukrân ve Bulûs tarafında deniz ile Mukrân arasında kalan çöl, batısı Fars, kuzeyi Horasân çölüve Sicistân, güneyi Fars denizidir. ${ }^{109}$ Kirmân'ın Sarûd/ Soğuk İklim ve Cerûm/ Sıcak İklim bölgeleri vardır. Sarûd'un/ Soğuk İklim soğukluğu Fars'ın Sarûd'unun/ Soğuk İklim soğukluğundan geri kalmaz. Cerûmlarında/ Sıcak İklim soğukluktan bir eser yoktur. ${ }^{110}$

Daha sonra bölgenin dağlarını ve Cîruft, Bemmü, Şîrecân, Magûn, Şehrû ve Zerend gibi şehirlerini konu edinir. ${ }^{111}$ Folklorik olarak bölge halkının dillerinden bahseden İstahrî, "Kirmân halkının dili Farsçadır. Kufs halkı Farsça dışında Kufsîce dili konuşur. Benzer şekilde Bulûs ve Bâriz yerleşimlerinde de Farsça'nın dışında konuşulan bir başka dil vardır.” bilgisini verir. ${ }^{112}$ Son olarak, şehirler arasındaki mesâfeleri vererek bu bölgeyi tamamlar. ${ }^{113}$

\section{Sind Ülkesi}

Sind'i "Hind, Mukrân, Tûrân ve Budha ülkelerinin bir parçası" olarak tanımlayan İstahrî, Kenbâye, Mansûra, Multân,Semed, Rûr, Bîrûn, Menhâterâ, Mesvâhî, Behrec,

\footnotetext{
${ }^{107}$ İstahrî, Mesâlik, s. 156.

${ }^{108}$ İstahrî, Mesâlik, s. 157.

${ }^{109}$ İstahrî, Mesâlik, s. 158.

${ }^{110}$ İstahrî, Mesâlik, s. 159.

${ }^{111}$ İstahrî, Mesâlik, ss. 160-167.

${ }^{112}$ İstahrî, Mesâlik, s. 167.

${ }^{113}$ İstahrî, Mesâlik, ss. 168-170.
} 
Sedûsân, Ennerî, Kannerî, Meyd, Râhûk, Keluvân ve Kusdâr şehirlerinden bahseder. ${ }^{114}$ Bölge hakkındaki bilgileri mesâfeleri vererek bitirir. ${ }^{115}$

\section{3. İrmeniye, Rân, Âzerbaycân}

İstahrî, bu 3 bölgeyi tek bir başlık altında ele almıştır. Bölgeyi "Doğusunda Cibâl ve Deylem, batısında bu bölgeyi batı yönünde kuşatan Hazar denizi, İrmen sınırları, Lân ve elCezîre sınırının bir bölümü, kuzeyinde Lân ve Kabk dağları, güneyinde Irak sınırı ve elCezîre'nin bir bölümü vardır." şeklinde tanımlar. ${ }^{116}$ Erdebîl, Merâga, Urmiye, Berza'a', Bâbü'l-Ebvâb ve Tiflis konu edindiği başlıca şehirlerdir. ${ }^{117}$ Mesâfeleri vererek bölgenin anlatımını bitirir. ${ }^{118}$

\section{Cibâl}

Cibâl yöresini "Mâhu Kûfe ${ }^{119}$ ve Basra'nın kenarından başlar. Böylelikle Cibâl arazisine girmiş olur. Doğusu Horasân çölü/ Mefâzetu Horasân, Fars, Isfahan ve Huzistân, batısı Âzerbaycân, kuzeyi Kazvin ve Rey’dir. Biz Kazvin, Rey, Ebher ve Zencân’ı ayırdık ve onları Deylem bahsinde ele aldık. Zira buralar Cibâl'e bir yay gibi durur. Güneyi Irak ve Huzistân'dır." şeklinde belirleyen ${ }^{120}$ İstahrî, hemen ardından bölgedeki mesâfeleri verir. ${ }^{121}$ Dinever, Hemedân, Isfahan ve Kum bu bölgede konu edindiği başlıca şehirlerdir. ${ }^{122}$

\section{Deylem}

Deylem'i “Güneyi Kazvîn, Tarm, Âzerbaycân'ın bir kısmı, Rey'in bir kısmı ve doğu yönünde ona bağlı kimi yerler, Taberistân ve ona bağlı kimi yerlerdir. Kuzeyi Hazar denizi, batısı Âzerbaycân'ın bir kısmı ve Rân ülkeleridir.” şeklinde tanımlayan ${ }^{123}$ İstahrî, bu bölgede başlica Rey, Huvâr, Kazvîn, Âmul, Cürcân ve Esterâbâz şehirlerinden bahseder ${ }^{124}$ ve mesâfeleri vererek bölge hakkındaki bilgileri tamamlar. ${ }^{125}$

\footnotetext{
${ }^{114}$ İstahrî, Mesâlik, ss. 171-178.

${ }^{115}$ İstahrî, Mesâlik, ss. 178-180.

${ }^{116}$ İstahrî, Mesâlik, s. 181.

${ }^{117}$ İstahrî, Mesâlik, ss. 181-189.

${ }^{118}$ Istahrî, Mesâlik, ss. 191-194.

119 Mâhu Kûfe, bu bölgenin fethine katılan ve Kûfe'de bulunan ordunun giderleri bu şehrin vergilerinden karşılandığı için Kûfe 'nin arpalı̆̆ $\mathrm{anlamına} \mathrm{Mâhu} \mathrm{Kûfe} \mathrm{denilmiştir.}$

${ }^{120}$ İstahrî, Mesâlik, s. 195.

${ }^{121}$ İstahrî, Mesâlik, ss. 195-197.

${ }^{122}$ İstahrî, Mesâlik, ss. 197-203.

${ }^{123}$ İstahrî, Mesâlik, s. 204.

${ }^{124}$ İstahrî, Mesâlik, ss. 206-213.

${ }^{125}$ İstahrî, Mesâlik, ss. 214-217.
} 


\section{Hazar Denizi}

İstahrî’nin eserinde konu edindiği 3. denizdir. "Bu denizin yeryüzünde başka denizlerle bağlantısı yoktur. Eğer birisi bu denizin etrafını dolaşmak istese, sadece suyu tatlı bir nehir dışında herhangi bir engel ile karşılaşmadan başladığı yere geri döner. Suyu tuzlu ve çamur bir denizdir. Kıyılarında med-cezir olmaz. Karanlık bir denizdir. Kulzum denizi ve diğer Fars denizinin aksine dibi çamurdur.” ifadeleriyle bu denizi tanımlayan İstahrî, ${ }^{126}$ Hazar bölgesi hakkında da bilgi verir: "Hazar bu iklimin ismidir. Bölgenin merkezî yerleşiminin ismi İtil/ Esil'dir. İtil/ Esil bir nehir adıdır. Rus topraklarından Bulgâr topraklarına doğru akar. İtil/ Esil iki bölümden oluşur; biri bu nehrin batısıdır ve İtil/ Esil adındadır. Büyük olanı burasıdır. Diğeri doğuda olan bölümdür. Hükümdâr bu iki kesimden batıda oturur ve kendi lisanlarında ona bek/ bey denir.",127

Serîr, Burtâs, Bescirt ve Bulgâr bu başlık altında bahsettiği şehirler ve bölgelerdir. ${ }^{128}$

\section{Horasân Çölü}

Horasan çölünü diğer coğrafyacıların aksine başlı başına ele alan İstahrî, sınırlarını “doğusu Mukrân sınırları ve bir kısım Sicistân sınırları, batısı Kûmıs sınırları, Rey, Kum ve Kâşân, kuzeyi Horasân sınırları ve bir kısım Sicistân sınırları, güneyi Kirmân sınırları, Fars ve bir kısım Isfahân sınırlarıdır." şeklinde belirler. "İslâm ülkelerinde büyüklüğüne oranla insan yerleşiminin, köylerin ve şehirlerin en az bulunduğu bölgedir.” ifadesiyle de Horasan çölünü vasiflar. $^{129}$

Çölün etrafında yer alan Fars yönünde Nâin, Isfahân yönünde ve Kirmân sınırında Yezd, Ukde ve Erdistân, Cibâl sınırında Habîs, Zâver ve Nermâşîr gibi şehirlerden bahseden ${ }^{130}$ İstahrî, devam sayfalarında çöldeki güzergâhlar hakkında bilgi verir. ${ }^{131}$

\section{Sicistân}

“Doğusu Kirmân ile Sind arazisi arasında kalan çöl/ mefâze ve Multân’ın bir kısmıdır. Batısı Horasân ve Hind arazisinin bir kısmıdır. Güneyi Sicistân, Fars ve Kirmân arasında

\footnotetext{
${ }^{126}$ İstahrî, Mesâlik, s. 218.

${ }^{127}$ İstahrî, Mesâlik, s. 220.

${ }^{128}$ İstahrî, Mesâlik, ss. 225-227.

${ }^{129}$ İstahrî, Mesâlik, s. 227.

${ }^{130}$ İstahrî, Mesâlik, s. 229.

${ }^{131}$ İstahrî, Mesâlik, ss. 229-237.
} 
kalan çöldür/ mefâze." ifadeleriyle Sicistân'ın sınırlarını belirleyen ${ }^{132}$ İstahrî, daha sonra detaylı olarak en büyük şehri Zerenc'den bahseder. ${ }^{133}$ Bölgedeki nehirleri anlattıktan sonra Bâlis, Zühhac, Büst, Karnîn, Tâk, Huvâş̧, Cizeh Servân ve Rûzân gibi bölgenin önemli şehirlerini anlatır. ${ }^{134}$ Konunun sonunda bölgedeki mesâfeler hakkında bilgi verir. ${ }^{135}$

\section{Horasân Bahsi}

Horasân, İstahrî'nin üzerinde detaylı olarak durduğu başlıklardan birisidir. Horasân'ın sınırlarını "Burası bir iklimin ismidir. Doğusu Sicistân civarı ve Hind ülkesidir. Batısı Oğuz çölü/ Mefâzetü Guzziyye ve Cürcânhavâlisidir. Kuzeyi Mâverâünnehir ve Huttel'in arka kısmına düşen bir kısım Türk ülkeleridir. Güneyi Fars çölü/ Mefâzetü Fars ve Kûmıs'tır. Bütün burayı da bir iklim olarak ele aldık." şeklinde belirler. ${ }^{136}$

İstahrî’nin Horasan tasnifi şu şekildedir: “Horasân'ın bölgeleri/ kuver, arazilere göre bir araya gelir veya ayrılır. Bunların en büyüğü Nîsâbûr'dur.Diğerleri, Merv ve Herât'tır. Horasân'da bunların dışında büyüklüklerine göre bölgeler vardır. Bunlar Kuhistân, Tûs, Nesâ, Ebîverd, Serahs, Esfizâr, Bûşenc, Bâzegîs, Kencü Rüstâk, Merverûz, Cûzecân, Garc eş-Şâr, Bâmiyân, Tuhâristân, Zemmü ve Âmul'dur."137

Îstahrî, Nîsâbûr, Merv ve Herât'ı detaylı olarak anlatır:

- "Nîsâbûr, Ebreşehir'dir. Düz arazide kurulu bir şehirdir. Binâları çamurdandır ve dağınık bir haldedir. 1 fersaha 1 fersahlık bir alana yayılmıştır. Buranın bir merkezî şehri, eski kalesi ve dış mahalli vardır. Eski kalesi ve merkezî şehri bayındırdır. Cuma Mescidi dış mahalde, garnizon olarak bilinen yerdedir. Hükümet Merkezi Hüseyniyyîn olarak bilinen meydandadır. Hapishane, Hükümet Merkezinin yanındadır. Hapishane, Hükümet Merkezi ve Cuma Mescidi arası yaklaşık 1 fersahtır. Hükümet Merkezi, Amr b. Leys'in binâsının içindedir. Eski kalenin 1 kapısı, merkezî şehrin 4 kapısı vardır. Bu kapıların ilki Bâbu Ra'sü’lKantara, ikincisi Bâbu Sikket-i Ma'kıl, üçüncüsü Bâbu'l-Kuhendiz ve dördüncüsü Bâbu Kantaratu Tekîn'dir. Eski kale şehrin dışındadır."138

- “Merv, aslında Mervü’ş-Şâhcihân olarak bilinir. Eski zamanlarda kurulmuş bir şehirdir. Söylenildiğine göre eski kaleTahmûrs'un binâsıdır. Eski şehir Zî’l-Karneyn’in

\footnotetext{
${ }^{132}$ İstahrî, Mesâlik, s. 238.

${ }^{133}$ İstahrî, Mesâlik, ss. 240-243.

${ }^{134}$ İstahrî, Mesâlik, ss. 243-248.

${ }^{135}$ İstahrî, Mesâlik, ss. 248-252.

${ }^{136}$ İstahrî, Mesâlik, s. 253.

${ }^{137}$ İstahrî, Mesâlik, ss. 253-254.

${ }^{138}$ İstahrî, Mesâlik, s. 254.
} 
kurduğu bir şehirdir. Dağlardan uzak, düz bir arazidir. Şehirden bakıldığında dağ görülmez ve ayrıca sınırları içerisinde dağ yoktur. Arazisi tuzlu ve kumludur. Kum çoktur. Binâları çamurdandır. 3 tane Cuma Mescidi vardır. Ancak bu 3 Cuma Mescidi içerisinde ilk namaz kılınanı, şehrin içerisindedir ve ilk İslâm dönemlerinde inşâ edilmedir.",139

- "Herât, etrafında sağlam bir kale duvarı/ sûr bulunan bir şehirdir. Etrafı sudur. Şehrin içi bayındırdır/ mamur. Etrafında bir dış mahal bulunur. Şehirde bir kale ve Cuma Mescidi mevcuttur. Hükümet Merkezi şehrin içindedir. Kalenin dışında bulunan Horasânâbâz olarak bilinen yer, şehirden 1/3 fersah kadar uzaktır. Burası Bûşenc yolu üzerinde ve Herât'ın batısındadır. Binâları çamurdandır. Yaklaşık 0.5 fersahlık bir alandır. Merkezî şehrin 4 kapısı vardır. Bunlardan ilki, kuzey yönünde ve Belh'e doğru çıkılan Bâbu Serây, bir diğeri batı yönünde Nîsâbûr'a doğru çıkılan Bâbu Ziyâd, bir diğeri güney yönünde Sicistân'a doğru çıkılan Bâbu Fîrûzâbâd, sonuncusu doğu yönünde Gûr'a doğru çıkılan Bâbu Huşk'tur."140

Devam sayfalarında bölgedeki diğer şehirler hakkında bilgi veren ${ }^{141}$ İstahrî, konunun sonuna doğru bölgenin nitelikleri hakkında bilgi verir: "En kıymetli binek hayvanları Belh ve civarından, köleler Türk ülkelerinden, en kıymetli pamuklu ve ipekli giysiler Nîsâbûr ve Merv'den, keten kumaşlar Merv'den, eti en lezzetli koyunlar da Oğuz/ Guzziyye ülkelerinden getirilir. En tatlı ve hafif su, Ceyhûn'un suyudur. En müreffeh Horasân toplumu Nîsâbûr halkıdır. En necîb Horasân toplumu Belh ve Merv halkıdır. Fıkıh, dinî ilimler, münâzara ve kelâm alanlarında en zeki olanlar Nîsâbûr halkıdır. En sağlıklı olan yöre, Belh ile Merverûz arasıdır. Horasân'ın Cerûm/ Sicak İklim bölgesi sadece Fars ve Kirmân arasında kalan Kuhistân bölgesidir. Soğuğu ve karı en şiddetli olan yer Bâmiyân ve Harzem'dir."142

İstahrî, şehirler arasındaki mesâfeleri vererek Horasân bahsini bitirir. ${ }^{143}$

\section{Mâverâünnehir}

Mâverâünnehir, İstahrî’nin detaylı olarak bahsettiği son bölgedir. Bölgenin sınırlarını “doğusu Fâmir, Râşt ve düz bir istikâmette Hind arazisinden Huttel'e doğru Huttel'in arka kesimleridir. Batısı Oğuzlar/ Guzziyye ve Karluklar/ Hazleciyye ülkeleri, Tarâz sınırında yay şeklinde uzanarak Fârâb, Bîskend, Sogd/ Sugd, Semerkand civarı, Buhârâ, Harzem ülkesi ve Harzem gölüdür.Kuzeyi Fergâna'nın uzaklarından Taraz’a doğru Türk ve Karluklar/ Hazleciyye ülkeleridir. Güneyi Bezehşân'dan Harzem gölüne doğru düz bir istikâmette

\footnotetext{
${ }^{139}$ İstahrî, Mesâlik, s. 258.

${ }^{140}$ İstahrî, Mesâlik, s. 264.

${ }^{141}$ İstahrî, Mesâlik, ss. 266-282.

${ }^{142}$ İstahrî, Mesâlik, s. 282.

${ }^{143}$ İstahrî, Mesâlik, ss. 282-286.
} 
Ceyhûn nehridir. Biz Harzem ülkesi ile Huttel'i Mâverâünnehir bahsine koyduk; zira Huttel, Ceryâb ile Vahşâb nehirleri arasındadır. Ceryâb nehri de Ceyhûn nehrinin ana koludur. Bunun altında kalan kesimler Mâverâünnehir ve Harzem'dir. Harzem şehri nehrin ötesindedir. Ayrıca Harzem şehri Maverâünnehir şehirlerine Horasân şehirlerinden daha yakındır." şeklinde belirler. ${ }^{144}$

İstahrî, Mâverâünnehr'i anlatırken övücü sözler kullanır: "Maverâünnehir, İslâm ülkelerinin en bereketlisi, nezihi, halkı ve hayrı en bol olanıdır. Hayra çok rağbet ederler. Kim çağırırsa yardımına koşarlar, Huzursuzlukları azdır ve selâmet bir ülkedir. Ellerinde bulunan imkânları, âletleri, el ve ayakları/ kurâ' ${ }^{145}$ ve silahları ile kötülüğün yok olmasına ve iyiliğin egemen olmasina harcarlar."146

"Uşrûseneli Afşîn ${ }^{147}$ ve Âl-i Ebi's-Sâc, ${ }^{148}$ Semerkandlı Ihşîd, Sogdlu/ Sugd ve Buhârâlı Merzubân b. Türkesfî̀ ve Uceyf b. Anbese gibi Türkler cesaretleri ve yiğitlikleri dolayısıyla hilâfete hâkim oldular. Aynı şekilde halifenin emirleri, komutanları ve askerleri haline geldiler." ifadeleriyle Türk komutanlardan bahseden İstahrî, ilerleyen satırlarda

\footnotetext{
${ }^{144}$ İstahrî, Mesâlik, ss. 286-287.

${ }^{145}$ Kurâ', hayvanların el ve ayaklarından yapılan eşya anlamında kullanılmaktadır.

${ }^{146}$ İstahrî, Mesâlik, s. 287.

147 Afşîn, Abbâsî halifeleri Me'mûn ve Mu'tasım'ın meşhur Türk kumandanıdır. (ö. 226/841) İslâmî fetihler sırasında Mâverâünnehir'deki Üşrûsene bölgesi hükümdarlarına verilen bir unvan olan afşin kelimesi, kökü bilinmeyen bir özel isim olarak Orta dönem Farsça'sında geçen pişînin Arapçalaştırılmış şeklidir. Bu bölgedeki son ve en meşhur hükümdar Afşin Haydar b. Kâvûs'un mensup olduğu ailenin ne zamandan beri Üşrûsene'de hüküm sürdüğü kesin olarak bilinmemekle birlikte, milâdî VII. yüzyılın ortalarında Göktürk Kağanlı̆̆g'nın zayıflaması üzerine Mâverâünnehir'deki diğer küçük devletlerle beraber ortaya çıktığı söylenebilir. Bu aileden tesbit edilebilen ilk şahıs olan Hara (Kara) Buğra’nın (بغره خره) 736 yılında Horasan Valisi Esed b. Abdullah elKasrî ile Türgiş Kağanı Su-lu arasındaki savaşta Su-lu Kağan'ın safında yer aldığı bilinmektedir. Kara Buğra'nın oğlu ve Afşin'in dedesi Han Hara (Kara) (خره خان), (794-) yılında Horasan Valisi Fazl b. Yahyâ el-Bermekî ile mücadele etmişti. Babası Kâvûs, Halife Me'mûn zamanında Abbâsî hâkimiyetini kabul etmiş, ancak Me'mûn'un Bağdat'a dönmesinden sonra (819) tekrar bağımsızlığını kazanmıştı. Bu sırada Kâvûs ailesi arasında çıkan bir anlaşmazlık sebebiyle Bağdat'a gelerek Müslümanlığı kabul eden Afşsin, Me'mûn'un gönderdiği orduya rehberlik ederek Üşrûsene'nin fethini sağladı. Abbâsîler' in hizmetine ne zaman girdiği belli değildir; ancak 206 (821-22) yılında Bağdat'a gelmiş olması kuvvetle muhtemeldir. Bkz.: Hakkı Dursun Yıldız, "Afşin, Haydar b. Kâvûs", DIA, C.: 1, ss. 441-442.

${ }^{148}$ Muhammed b. Ebu's-Sâc, Ebü'l-Müsâfir (Ebû Ubeydillâh) el-Afşîn Muhammed b. Ebi’s-Sâc Ya ‘kūb Dîvdâd b. Yûsuf Dîvdesttir. (ö. 288/901) Sâcoğulları hânedanının kurucusu ve ilk hükümdarıdır. (889-901) Mâverâuinnehir'in Üsrûşene (Uşrusana) bölgesinin yerli halkından Ebü’s-Sâc Ya'kūb Divdâd b. Yûsuf Divdest'in oğludur. Bölgenin hükümdar ailesi mensuplarından Haydar b. Kâvûs el-Afşin'in kumandanlarından olan Divdâd daha sonra Abbâsîler'in hizmetine girerek önemli görevler üstlenmiştir. Kaynaklarda Afşîn b. Divdâd ve İbn Ebü's-Sâc adlarıyla da zikredilen Muhammed b. Ebü's-Sâc babasının ölümünün ardından, Halife Mu'temid-Alellah' ın nâibi sıfatıyla iktidarı elinde tutan kardeşi Muvaffak-Billâh tarafından Tarîķimekke ve Haremeyn valiliğine tayin edildi (266/880). Bkz.: Faruk Sümer, "Muhammed b. Ebu's-Sâc”, DİA, C.: 30, ss. $524-526$
} 
şehirlerden bahseder. Buhârâ, Semerkand, Huttel, Vahş, Tirmiz ve Vâşecird gibi şehirler hakkında bilgi verir. ${ }^{149}$

Hârezm bölgesini Mâverâünnehir başlı̆̆ı altında değerlendirir. ${ }^{150}$ Nehirler ve mesâfeler hakkında verdiği bilgiler ile Mâverâünnehir anlatımını bitirir. $^{151}$

\section{Sonuç}

20 Bölüm olarak hazırlanan bu çalışma, dönemin dünyasını anlamamıza katkı sağlamaktadır. Zira, şehirler, şehirlerin yapıları, arazileri, yetiştirilen ürünler, sanayii malları olarak değerlendirebileceğimiz eşyalar vs. hakkında zengin içerikli bilgiler bulunmaktadır. Ayrıca, kılık-kıyafet ve giysiler, kullanılan paralar, ağırlık ölçüleri, bölgenin ekonomik değerleri ve vergileri, bölge halklarının özellikleri gibi konular da İstahrî tarafından açıklanmıştır.

Eser, yazarının bizzat görerek elde ettiği bilgilerden oluşması nedeniyle daha da önemlidir. Özellikle kendi yöresi olan Fars ve Horasân hakkında oldukça detaylı bilgiler bulmak mümkündür. Fars veHorasân bölgelerinin dışında Arap yurdu ile Mâverâünnehir, İstahrî’ninağırlıklı işlediği bölgelerdir. Özellikle bu 4 bölge hakkında teferruatlı bilgiler mevcuttur.

Müellif, kendisi İranlı olması hasebiyle, diğer coğrafyacıların aksine, İran coğrafyasına daha fazla önem vermiştir. Diğer müellifler, genellikle Bağdâd eksenli anlatım yaparlarken, İstahrî Fars, Horasân ve Sicistân ağırlıklı bir eser kaleme almıştır.

İslâm dünyası baz alınarak hazırlanan bu çalışma, Türkler hakkında verdiği bilgiler açısından da önemlidir. Her ne kadar, diğer coğrafya eserleri ilekıyaslandığında az miktarda olsa da, özellikle Mâverâünnehir coğrafyasının anlatımı son derece geniştir. Buhâra, Semerkand, Uşrûsene, Fergânâ, Merv gibi Türk şehirleri detaylı olarak anlatılmıştır.

\footnotetext{
${ }^{149}$ İstahrî, Mesâlik, ss. 287-299.

${ }^{150}$ İstahrî, Mesâlik, s. 299.

${ }^{151}$ İstahrî, Mesâlik, ss. 300-348.
} 


\section{KAYNAKÇA}

Ağarı, Murat (2002). İslâm Coğrafyacıllığı ve Müslüman Coğrafyacılar(DoğuşuGelişimi ve Temsilcileri), Kitabevi yay., İstanbul

Ağarı, Murat (2006). “İslam Coğrafyacılarında Yedi İklim Anlayışı”, Ankara Üniversitesi Illahiyat Fakültesi Dergisi, C: 47, Sayı: II, ss.: 157-176

Ağarı, Murat (2005). “Coğrafya Eserlerindeki Türklerle İlgili Bilgilerin Irak ve Belh Coğrafya Ekollerine Göre Değerlendirilmesi”, YYÜ Sosyal Bilimler Enstitüsü Dergisi,Sayı: 8, ss: $35-66$

Ahatl1, Erdinç, "Utbe b. Gazvân”, DİA, C.: 42, s. 235

Ak, Mahmut, "İklim", DIA, C.: 22, ss. 28-30

Aycan, İrfan,Rebîa(Benî Rebîa)”, DİA, C.: 34, ss. 498-499

Bozkurt, Nahide, "Mansur", DïA, C.: 28, ss. 5-6

Bozkurt, Nahide, "Mehdî-Billâh”, DİA, C.: 28, ss. 377-379

Bozkurt, Nebi, “Minber”, DIA, C.: 30, ss. 101-103

Bozkurt, Nebi, "Ravza-i Mutahhara”, “DIA, C.: 34, s. 475

Çelebi, İlyas, "Ye'cûc Me'cûc", DİA, C.: 43, ss. 373-375

Durmuş,İsmail, “İbnü’1-Mukaffa'”, DİA, C.: 21, ss. 130-134

Fayda, Mustafa, "Ebû Bekir”, DİA, C.: 10, ss. 101-108

Fayda, Mustafa, “Ömer”, DIA, C.: 34, ss. 44-51

Harman, Ömer Faruk, "Danyal”, DİA, C.: 8, ss. 480-481

Harman, Ömer Faruk, "Lût", DIA, C.: 27, ss. 227-229

Hatiboğlu, İbrahim, "Selmân-1 Fârisî”, DİA, C.: 36, ss. 441-443

İstahrî, Ebî İshak İbrahim b. Muhammed el-Fârisî (1927)Mesâlikü’l-Memâlik, Brill

Kallek, Cengiz, “Men”, DIA, C.: 29, ss. 105-107

Kallek, Cengiz, "Miskâl”, DIA, C.: 30, ss. 182-183

Kandemir, M. Yaşar, “Ebû Mûsâ el-Eş’arî”, DİA, C.: 10, ss. 190-192

Kaya,Remzi, “Ehl-i Kitap”, DIA, C.: 10, ss. 516-519

Küçükaşçı,Mustafa Sabri, "Mudar(Benî Mudar)”, DİA, C.: 30, ss. 358-359

Merçil, Erdoğan, "Saffârîler”, DIA, C.: 35, ss. 464-465 
Öz, Mustafa, "Cennâbî, Ebû Saîd”, DIA, C.: 7, s. 371

Özbalıkçı, M. Reşit, “Sibeveyhî”, DİA, C.: 37, ss. 130-134

Sahillioğlu, Halil, “Dirhem”, DIA, C.: 9, ss. 368-371

Sümer, Faruk, “Muhammed b. Ebu's-Sâc”, DİA, C.: 30, ss. 524-526

Uludağ, Süleyman “Hallâc-1 Mansûr”, DİA, C.: 15, ss. 377-381

Terzi, Mustafa Zeki, “Ordu”, DIA, C.: 33, ss. 357-362

Yıldız, Hakkı Dursun, “Afşin, Haydar b. Kâvûs”, DIA, C.: 1, ss. 441-442

Yıldız, Hakkı Dursun, “Avâsım”, DIA, C.: 4, ss. 111-112

Yiğit, İsmail, "Mevâlî", DİA, C.: 29, ss. 424-426 